\title{
Analysis of the episodes of tropospheric ozone concentration in relation with hot days and heat waves in Warsaw
}

\author{
Katarzyna Rozbicka $^{1, *}$, Tomasz Rozbicki ${ }^{1}$ \\ ${ }^{1}$ Warsaw University of Life Sciences, Faculty of Civil and Environmental Engineering, \\ 166 Nowoursynowska St., 02-776 Warsaw, Poland
}

\begin{abstract}
The study presents the characteristics of the occurrence of smog episodes - days with exceeded the limit value of 8-hour tropospheric ozone concentration $\left(120 \mu \mathrm{g} \cdot \mathrm{m}^{-3}\right)$ with the occurrence of hot days (maximum air temperature greater than $25^{\circ} \mathrm{C}$ ), very hot (maximum air temperature greater than $30^{\circ} \mathrm{C}$ ) and heat waves during 13-year period 2004-2016 in the area of Warsaw, Poland. In the analyzed period, the average number of hot days was 45 , and very hot days was 8 . The highest number of these days occurred in 2015,54 and 20 days respectively. Heat waves were short and lasted usually 3-4 days. The highest number of them was recorded in 2010 and 2015 (14 days). The highest ozone concentration value $189 \mu \mathrm{g} \cdot \mathrm{m}^{-3}$ was recorded on 28 May 2005, thus exceeding the information threshold $\left(180 \mu \mathrm{g} \cdot \mathrm{m}^{-3}\right.$ for the value of 1 hour ozone concentration). However, the number of days with the exceeded limit value of ozone concentration was not in any year exceeded the target value, i.e. 25 days in a calendar year. The relatively stronger relationship $(\mathrm{R}=0.513)$ in comparison to others obtained between average maximum temperature during LTO exceedance days and average ozone concentration during these days but it was not statistically significant.
\end{abstract}

\section{Introduction}

Since the discovery of ozone and its first measurements in Europe at the end of the nineteenth century, background ozone concentrations have more than doubled, showing a significant increase during the last few decades, both in rural and urban areas e.g. [1,2]. The analysis of tropospheric ozone concentrations is highly important since, apart from being a greenhouse gas, its strong oxidant properties, at certain levels, can affect animals, vegetation, materials and have an effect on human health not only for predisposed patients, such as asthma sufferers and children, but also for previously healthy individuals [3, 4]. The annual cycle of ozone at background sites in the Northern hemisphere is clearly characterized by a spring maximum which may be broadened by local ozone production during the summer. The spring maximum may originate from both enhanced photochemistry in the free troposphere as well as from stratospheric-tropospheric exchanges $[5,6]$. Ozone episodes are defined as time

\footnotetext{
${ }^{*}$ Corresponding author: katarzyna rozbicka@sggw.pl
} 
periods when ozone concentrations near ground level exceed the air quality limit values established by legislation [7]. Its formation process is highly dependent on air mass exchange between the stratosphere and the troposphere, surface dry deposition, temperature, solar radiation, $\mathrm{NO}_{\mathrm{X}}$ emissions and environmental concentrations of volatile organic compounds e.g. $[8,9]$. Thus, most studies have shown a strong relationship between ozone concentration levels and solar radiation, air temperature, relative humidity and wind speed and direction e.g. [10-12]. Ozone episodes usually occur during sunny days, where strong solar radiation and high temperatures cause the reactions that lead to the formation of ozone and various other oxidizing species [13]. Stathopoulou et al. (2008) [14] showed that temperature is the main parameter affecting ozone concentration levels. A number of studies established that for the temperature range from $17^{\circ} \mathrm{C}$ to $32^{\circ} \mathrm{C}$ the increase of ozone concentration is approximately linear $[15,16]$. Biogenic emissions of ozone precursors also increase with temperature, which cause ozone formation. Relevant the role of surface dry deposition during the European 2003 summer heat wave, indicating that reduced uptake from vegetation due to drought contributed significantly to high ozone levels [17, 18]. Although the relation between temperature and ozone pollution was confirmed in numerous studies, only limited publications focus on photochemical pollution during hot days and heat waves. Ozone pollution during heat waves was analysed over Western Europe for August 2003 [19] and July 2006 over Central Europe [20, 21]. The assessment of ozone pollution in Athens during heat waves that occurred in the last decade was presented by Papanastasiou et al. (2014) [22]. A relatively high positive correlation between ozone and air temperature in terms of the probability of the number of days with ozone exceedances in respect to a given maximum daily temperature was found in North Rhine-Westphalia, Germany, for the period of 1983 2007 [23]. In over Poland Strużewska and Jefimow (2016) [24] analysed of surface ozone pollution in the context of hot spells episodes.

The aim of the presented study is to analyse a long-term variability of temperature characteristics and surface ozone concentrations based on measurements from WarsawUrsynow in Poland. An attempt was made to establish the relationship between the hot weather periods and ozone pollution in Warsaw. Also, the heat wave periods were identified and analysed in the context of high ozone episodes. In addition the heat wave periods were identified and analyzed in the context of occurrence together with high ozone episodes.

\section{Materials and methods}

The presented analyses were undertaken for the 13-year period 2004-2016. The hourly mean values of concentrations of tropospheric ozone $\left(\mu \mathrm{g} \cdot \mathrm{m}^{-3}\right)$ and air temperature $\left({ }^{\circ} \mathrm{C}\right)$ were use. The meteorological data came from meteorological station Warsaw-Ursynow-SGGW (WULS) Laboratory Water Centre which is located in the campus WULS $(\phi)=52^{\circ} 09^{\prime} \mathrm{N}$, longitude $(\lambda)=21^{\circ} 03^{\prime} \mathrm{E}$, and elevation $(\mathrm{H})=102.5 \mathrm{~m}$ a.s.l. Ozone measurements were obtained from the Warsaw conurbation managed by the government, namely, the Provincial Inspectorate for Environmental Protection's air quality monitoring stations on Wokalna street - Warsaw-Ursynow (code station PL0141A) (http://www.gios.gov.pl/pl). A both stations are located $400 \mathrm{~m}$ to each other. They are located in Ursynow, a southern district of Warsaw, on the outskirts of the city and $9 \mathrm{~km}$ from the city centre (Fig. 1). The data was homogenized with use of the quotient method and statistical Student's t-tests. Completeness of the data used in the analysis is over $90 \%$. 


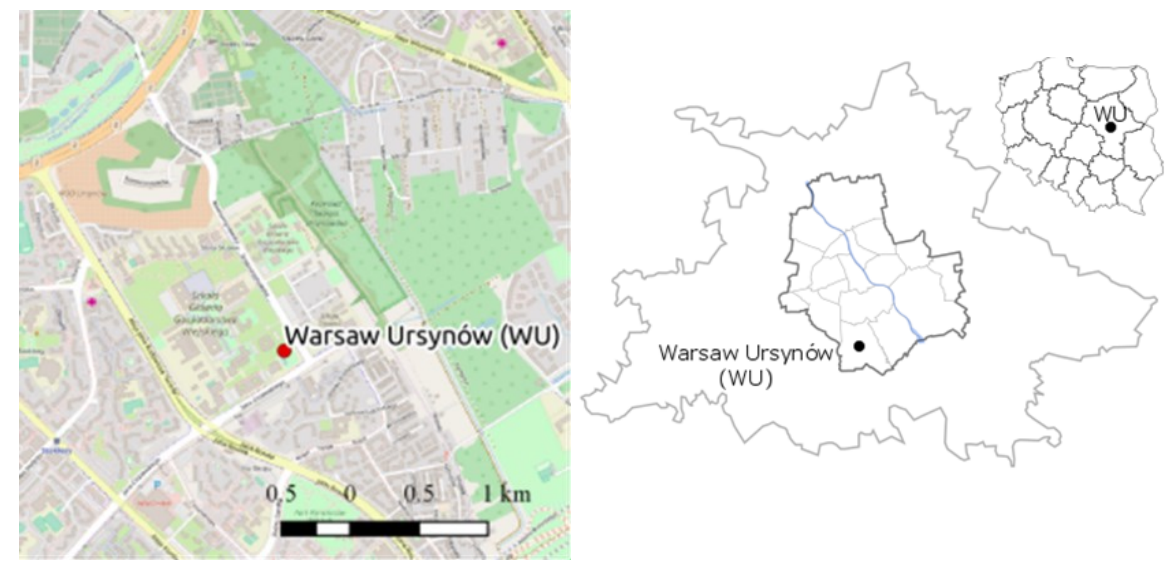

Fig. 1. Location of meteorological station - Warsaw Ursynów (WU).

The daily maximum temperature was used to analyse the climatology of hot weather periods in Warsaw. The following indexes were calculated: number of days with number of days with $\mathrm{T}_{\max }>25^{\circ} \mathrm{C}$ (hot days), average temperature during hot days, number of days with $\mathrm{T}_{\max }>30^{\circ} \mathrm{C}$ (very hot days), average temperature during very hot days, number of heat waves, defined as periods of at least three consecutive days with $\mathrm{T}_{\max }>30^{\circ} \mathrm{C}$. The number of very hot days is a subset of the number of hot days. A heat wave, defined as a prolonged period of excessively hot weather, is not precise and may vary depending on the region and climate type. In this work, we adopted a methodology based on temperature thresholds was adopted. In the works of e.g. [25-29] heat waves over Europe and Poland are defined as a period with at least three consecutive days with a maximum temperature exceeding $30^{\circ} \mathrm{C}$. To assess the impact of high temperature on ozone pollution, the following ozone concentration indexes were calculated: number of days with 8-hour moving average exceeding $120 \mu \mathrm{g} \cdot \mathrm{m}^{-3}$, daily maximum above the information threshold of $180 \mu \mathrm{g} \cdot \mathrm{m}^{-3}$. The occurrence of hot and very hot days, as well as the number of days with elevated ozone concentrations, were assessed for each year to assess trends and inter annual variability over the 13-year period. The European Directive on Ambient Air Quality and Cleaner Air for Europe (CAFE EC/2008/50) defines the thresholds for ozone exposure with respect to human health based on maximum daily 8 -hour running mean of ozone concentrations. The Long Term Objective (LTO) is defined as the number of days when the maximum 8-hour mean of ozone concentration exceeded $120 \mu \mathrm{g} \cdot \mathrm{m}^{-3}$. The target Value (TV) is exceeded when the LTO is exceeded more than 25 times per calendar year at a particular station. An attempt was made to explain the relationship between the length and intensity of hot days and the intensity of excessive ozone concentrations. Air quality monitoring in Warsaw has been carried out for several dozen years, however only as late as in 2004 it was adjusted to comply with the regulations and requirements of the EU. Since the monitoring system has been in operation, air quality can be recorded in order to warn the community of high levels of pollution as well as do research on the influence of air pollutants on human health [30-34]. 


\section{Results and Discussion}

\subsection{Temperature}

In the analyzed period 2004-2016 in Warsaw-Ursynow the highest number of hot days occurred in 2015 (54 days), in 2005 (53 days), 2016 (52 days) and 2012 (51 days), and the lowest number of hot days occurred in 2004 (30 days). Along with this, average maximum daily air temperature during hot days and very hot days were presented in the Fig. 2. The highest temperature during hot days occurs in $2015\left(29.7^{\circ} \mathrm{C}\right), 2006\left(29.2^{\circ} \mathrm{C}\right)$ and 2010 $\left(29.0^{\circ} \mathrm{C}\right)$. In other years) the temperature during hot days ranged between $27.3^{\circ} \mathrm{C}$ and $28.4^{\circ} \mathrm{C}$. In the year 2005 although the number of hot days was high, the average temperature during hot days was lower. During the analysed 13-year period the highest number of very hot days $\left(\mathrm{T}_{\max }>30^{\circ} \mathrm{C}\right.$ ) occurred in 2015 (20 days) and 17 days in 2006 and 2010. Strużewska and Jefimow (2016) [26] for Warsaw-Okęcie station obtained 22 and 17 of hot days for the years 2006 and 2010 respectively for the period 1997-2011. They associate this situation with the inflow of hot air masses from western Europe, which has an impact on the western part of Poland. The lowest number of very hot days occurred in 2011 ( 2 days) and in 2004 (3 days). During the analyzed period in 2008 very hot days were not observed. Similar results were obtained by Strużewska and Jefimow (2016) [26] where for none of the analysed stations there were not observed very hot days in 2008 and also in 2004 and 2005. At the WarsawUrsynów station in 2004 and 2005, the number of very hot days was one of the lowest of all. However, compared to the results from the Warsaw-Okęcie station, thermal diversity is observable, which is probably influenced by the type of the surface and the distance from the urban area. It could be supposed that this influence is smaller in case of peripheral and open space at the Warsaw-Okęcie station. Maximum temperature during very hot days ranged between $30.8^{\circ} \mathrm{C}(2009)$ and $33.5^{\circ} \mathrm{C}(2013)$ and $33.1^{\circ} \mathrm{C}(2015)$. Kossowska-Cezak (2014) [27] in other studies for Warsaw-Okęcie station obtained 33 hot days and 5 days very hot days per year in average in the period $1951-2010$. The increase in the number of characteristic days for warm period (hot and very hot days) as 2.2 per 10 years was shown and this increasing tendency stay after the year 2010.

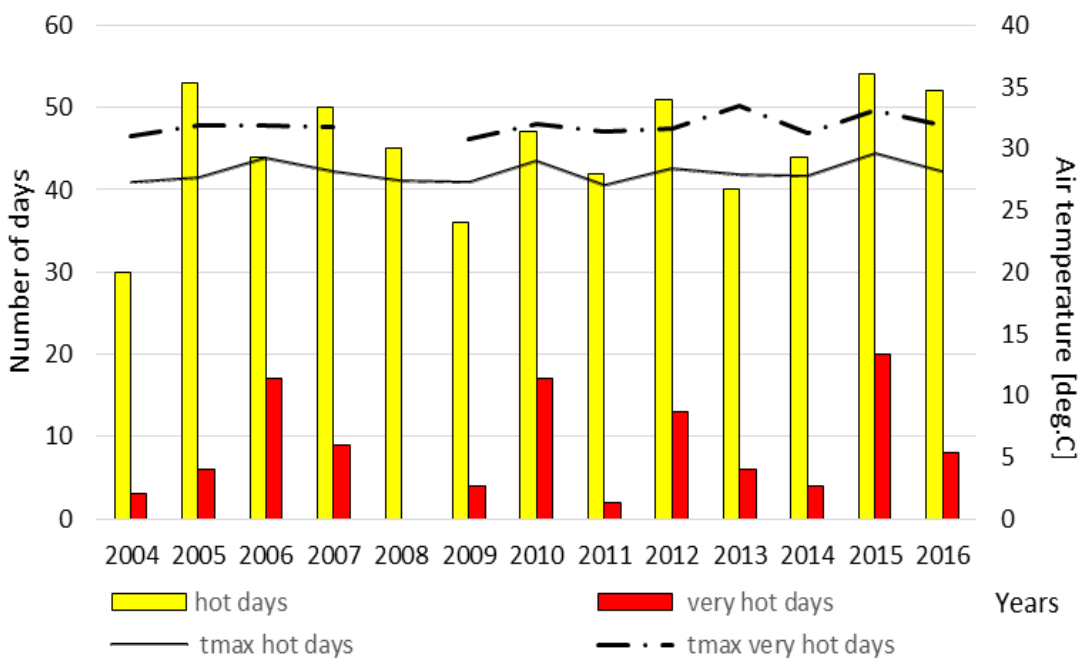

Fig. 2. Number of hot days and very hot days with average maximum temperature in 2004-2011, Warszawa-Ursynów. 
Based on the maximum temperature data, the heat wave periods, defined as at least three consecutive days with the maximum temperature exceeding $30^{\circ} \mathrm{C}$, were identified (Tab. 1). Usually the heat waves were short (3-4 days) in analysed period. In most cases 1-2 heat waves per year, occurred most often in July. The exception was 2006 and 2015 with 3 long periods of very hot weather. There were not heat waves in the years 2004, 2008, 2009 and 2011. The highest number of heat waves was recorded in 2010 and 2015 (14 days of 'hot spells'). The longest lasting and thus significantly burden heat waves were recorded in 2006 (5-13 Jul) and in 2015 (3-12 Aug), which were subjected detailed analysis. According to Strużewska and Jefimow (2016) in the year 2006, heat waves were rife and occurred over the same period.

Table 1. Heat wave periods (more than three consecutive days with $t_{\max }>30^{\circ} \mathrm{C}$ ) in 2004-2016, Warsaw-Ursynow.

\begin{tabular}{|c|c|c|}
\hline Years & Date & $\boldsymbol{\Sigma}$ days \\
\hline $\mathbf{2 0 0 5}$ & $\begin{array}{r}\text { 28-30 May } \\
\text { 28-30 Jul }\end{array}$ & $\mathbf{6}$ \\
\hline $\mathbf{2 0 0 6}$ & 5-13 Jul & $\mathbf{9}$ \\
\hline $\mathbf{2 0 0 7}$ & 15-17 Jul & $\mathbf{3}$ \\
\hline & $\begin{array}{r}\text { 10-13 Jul } \\
\text { 15-17 Jul } \\
2010\end{array}$ & $\mathbf{1 4}$ \\
& 13-16 Jul & \\
\hline $\mathbf{2 0 1 2}$ & 5-7 Jul & $\mathbf{3}$ \\
\hline $\mathbf{2 0 1 3}$ & 6-8 Aug & $\mathbf{3}$ \\
\hline $\mathbf{2 0 1 4}$ & 2-4.08 & $\mathbf{3}$ \\
\hline $\mathbf{2 0 1 5}$ & 4-7 Jul & $\mathbf{1 4}$ \\
\hline $\mathbf{2 0 1 6}$ & 3-12 Aug & $\mathbf{3}$ \\
\hline $\mathbf{2 0 0 4 - 2 0 1 6}$ & & $\mathbf{5 8}$ \\
\hline
\end{tabular}

\subsection{Ozone}

The number of days with exceeded LTO was calculated for each year of the analyzed period. Most days of LTO exceedances occurred in the years 2006, 2005 and 2015 19, 18 and 14 days respectively, which indicates that the target value (TV) was not exceeded in the analysed period. In the work the sum of hours with exceeded LTO was calculated, which was above 100 hours: in 2005 amounted to 137 hours, in 2006 amounted to 117 hours and in 2015 amounted to 107 hours. It can be noticed that the difference in the number of days with exceeding the LTO between the years 2006 and 2005 is only 1 day, however, in 2005 there were worse conditions in terms of air quality because the total hours exceeded the LTO was 20 hours higher. Maximum daily 8-hour running mean of ozone threshold (LTO) ranged between $129,1 \mu \mathrm{g} \cdot \mathrm{m}^{-3}$ (in 2012) and $169,7 \mu \mathrm{g} \cdot \mathrm{m}^{-3}$ (in 2005) (Fig.3). The threshold information value of ozone maximum concentration $\mathrm{O}_{3} 1$-hour $180 \mu \mathrm{g} \cdot \mathrm{m}^{-3}$ was exceeded three times in the analysed period. It occurred in 2005 on 28 May $\left(189 \mu \mathrm{g} \cdot \mathrm{m}^{-3}\right)$ and on $16 \mathrm{July}\left(183 \mu \mathrm{g} \cdot \mathrm{m}^{3}\right)$ and in 2005 on 5 May $\left(186.9 \mu \mathrm{g} \cdot \mathrm{m}^{-3}\right.$ ) (Fig. 4). Gawuć et al. (2013) [35] recorded that at Jarczew station in May 2006 and related to the advective episode the inflow from the eastern direction. 


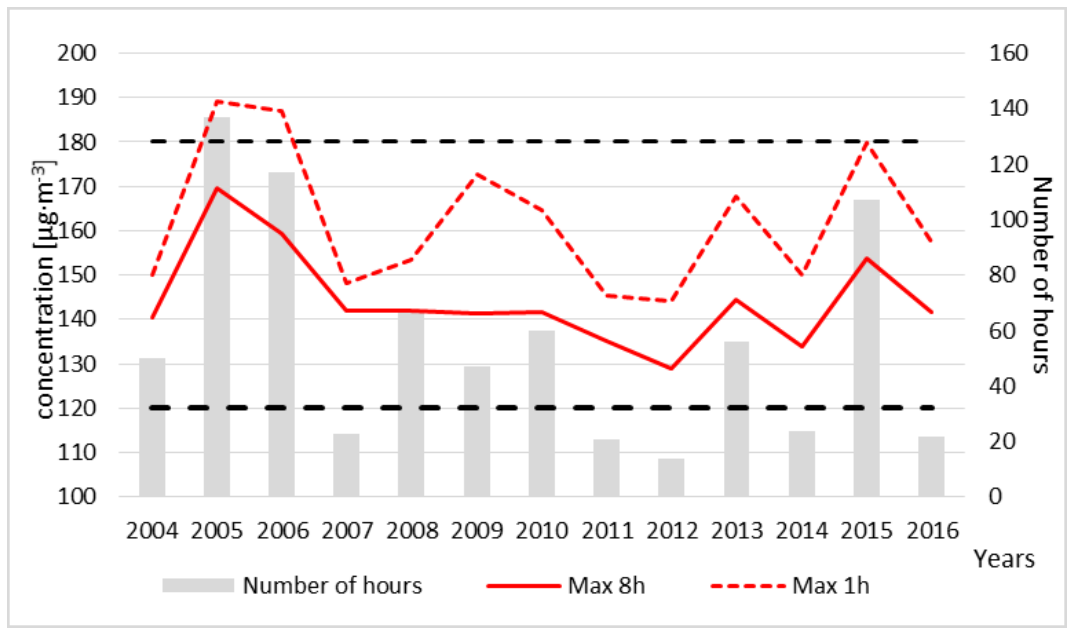

Fig. 3. Maximum 8-hour running mean and maximum 1-hour ozone concentrations with number of hours when ozone concentrations were above $120 \mu \mathrm{g} \cdot \mathrm{m}^{-3}, 2004-2016$ Warsaw-Ursynow.

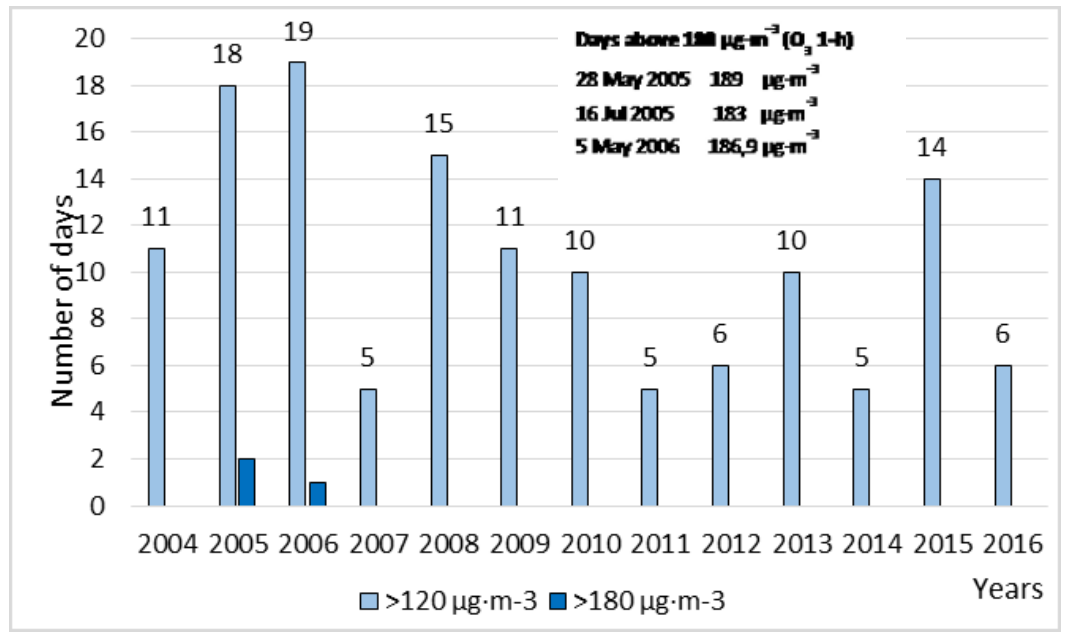

Fig. 4. Number of days with exceedances of $120 \mu \mathrm{g} \cdot \mathrm{m}^{-3}$ in respect to the maximum 8-hour running mean and $180 \mu \mathrm{g} \cdot \mathrm{m}^{-3}$ in respect to the maximum 1-hour of ozone concentrations for 2004-2016, Warsaw-Ursynow.

The relationship between the length and intensity of hot days and the intensity above the normative concentration of ozone was also examined (Fig.5). In the first approach, the relationship between the number of hot days in each year and the number of LTO exceedances was analysed. The temporal agreement between hot spells and episodes of high ozone concentration was taken into account. There was not statistically significant relationship for the analysed station $(\mathrm{R}=0.02)$. In the next approach the relationship between average 8-hour ozone concentration during hot days in each year was analyzed. During hot days the increase in ozone concentration was observed in relation to temperature. However, the correlation coefficient of this relationship was low $\mathrm{R}=0.283$ and not statistically significant. The dependence is not clear due small range of variability the temperature during hot days. Average 8-hour ozone concentration during hot days was lower than threshold value 
$120 \mu \mathrm{g} \cdot \mathrm{m}^{-3}$. In the last approach the relationship between average maximum temperature during LTO exceedance days and average ozone concentration during these days was analysed. The correlation coefficient was relatively stronger $(\mathrm{R}=0.513)$ in comparison to others but it was also not statistically significant $(\alpha=0.05)$. The small number of data considered in the analysis influenced the significance of these relationships. The highest relationship is observed in case of 8-hour ozone concentration and average maximum temperature during these days.
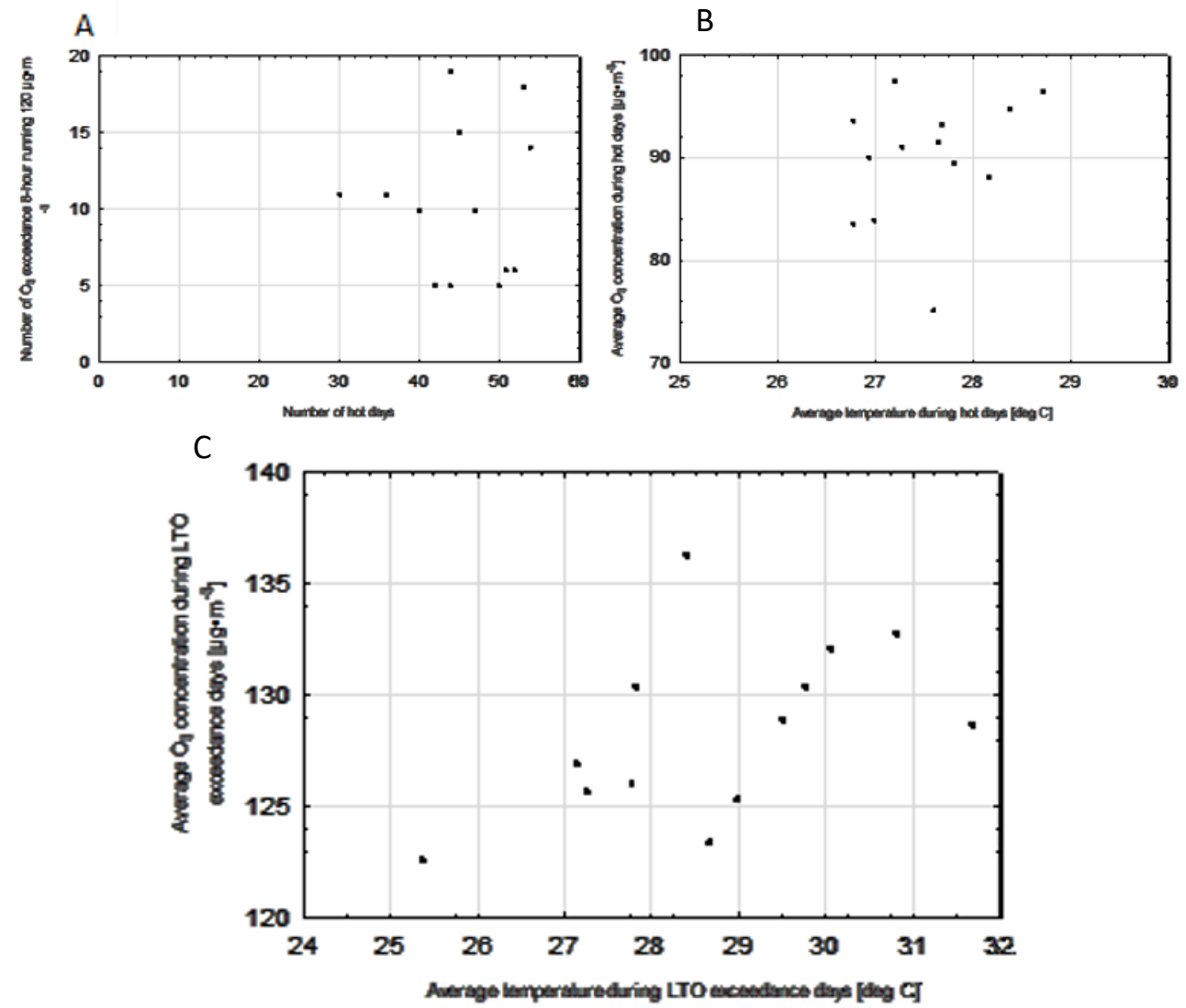

Fig. 5. Number of hot days with number of LTO exceedances A), maximum temperature with the average 8-hour ozone concentration during hot days B) and maximum temperaturę with the average 8-hour ozone concentration during days with LTO exceedances C), Warsaw-Ursynow 2004-2016.

\section{Conclusions}

The number of days with the maximum temperature exceeding $25^{\circ} \mathrm{C}$ 'hot days' and the number of days with the maximum temperature exceeding $30^{\circ} \mathrm{C}$ 'very hot days' for the 13 year period (2004-2016) in Warsaw-Ursynów station amounted to 45 and 8 days, respectively. The highest number of 'hot days' and 'very hot days' occurred in the year 2015, 54 and 20 days respectively, and the lowest in 2004, 30 and 3 days respectively. During the analysed period 'very hot days' were not observed in 2008. The maximum temperature during 'hot days' ranged between $27.3^{\circ} \mathrm{C}$ and $29.7^{\circ} \mathrm{C}$ and during 'very hot day' ranged between $30.8^{\circ} \mathrm{C}$ and $33.5^{\circ} \mathrm{C}$. 
Although it is believed that high air temperature results in an enhanced ozone formation, the outcome from the presented analysis of the relationship between hot weather periods and enhanced ozone pollution in Poland is not clear [26]. Similar results obtained Strużewska and Jefimow (2016) high exposure to ozone concentrations in terms of values higher than 120 $\mu \mathrm{g} \cdot \mathrm{m}^{-3}$ is correlated with the number of hot days. However, occurrence of very hot days, if not associated with longer hot weather periods, did not result in enhanced ozone pollution. The relatively stronger relationship $(\mathrm{R}=0.513)$ in comparison to others obtained between average maximum temperature during LTO exceedance days and average ozone concentration during these days but it was not statistically significant.

Recent studies [36, 37] of thermal extremes during summer months in Poland in 19512010 showed increasing frequency of the number of extremely warm days in a year and also the increase of the maximum number of consecutive hot days in a year. In Central Europe, hot spells can be associated with an inflow of two different types of air masses (subtropical from the south or transformed polar from westerly directions), which indicate the differences in contribution of transboundary transport of ozone and its precursors. For a more detailed explanation and analysis of relationships between episodes of high ozone concentration during hot days, a separate, more detailed analysis of selected episodes is needed. Such episodes should be connected with the synoptic situation, the inflow of air masses and meteorological conditions, which will be taken in further work.

\section{References}

1. A. Volz, D. Kley, Nature 332, 240-242 (1988)

2. E. Paoletti, A. De Marco, D.C.S. Beddows, R.M. Harrison, W.J. Manning, Environ. Pollut. 192, 259-299 (2014)

3. C. Yanga, H. Yang, S. Guo, Z. Wang, X Xu, X Duan, H. Kan, Sci. Total Environ. 426, 83-89 (2012)

4. J.I. Halonen, T. Lanki, P. Tiittanen, J.V. Niemi, M. Loh, J. Epidemiol. Community Health 64, 9, 814-820 (2010)

5. R. Vingarzan, Atmos. Environ. 38, 3431-3442 (2004)

6. P.S. Monks, Atmos. Environ. 34, 3545-3561 (2000)

7. M. Arsic, D. Nicolic, P. Djordjevic, I. Mihajlovic, Z. Zivkovic, Atmos. Environ 45, 57165724 (2011)

8. R. Yadav, L.K. Sahu, G. Beig, S.N.A. Jaaffrey, Atmos. Res. 176-177, 96-107 (2016)

9. A. Monteiro, A. Strunk, A. Carvalho, O. Tchepel, A.I. Miranda, C. Borrego, S. Saavedra, A. Rodriguez, J. Souto, J. Casares, E. Friese, Environ. Pollut. 162, 176-189 (2012)

10. G. Beaney, W.A. Gough, Atmos. Environ. 36(14) 2319-2325 (2002)

11. A. de Souza, E. Kovać-Andrić, B. Matasović, B. Marković, Water Air Soil Pollut. 227313 (2016)

12. K. Rozbicka, G. Majewski, T. Rozbicki, Meteorol. Zeit. 23 (2) 175-179 (2014)

13. B.J. Finlayson-Pitts, JN Jr Pitts, Elsevier Inc. San Diego (2000)

14. E. Stathopoulou, M. G. Mihalakakou, M. Santamouris, H.S. Bagiorgas, J. Earth Syst. Sci. 117 (3) 227-236 (2008)

15. B.J. Bloomer, J.W. Stehr, C.A. Piety, R.J. Salawitch, R.R. Dickerson, Geophys. Res. Lett. 36 L09803 doi:10.1029/2009GL037308 (2009)

16. L. Camalier, W. Cox, P. Dolwick, Atmos. Environ. 41 (33) 7127-7137 (2007) 
17. M. Vieno, A.J. Dore, D.S. Stevenson, R. Doherty, M.R. Heal, S. Reis, S. Hallsworth,

L. Tarrason, P. Wind, D. Fowler, D. Simpson, M.A. Sutton Atmos.Chem.Phys. 10, 16, 7963-7978 (2010)

18. S. Solberg, Ø. Hov, A. Søvde, I.S.A. Isaksen, P.Coddeville, H.De Backer, C. Forster, Y. Orsolini, K. Uhse, J. Geophys. Res. 113, D7, D07307 (2008)

19. E. Pellegrini, G. Lorenzini, C. Nali, Water Air Soil Poll. 181, 1, 401-408 (2007)

20. J. Strużewska, W. Kamiński, Atmos. Chem. Phys. 8, 721-736 (2008)

21. M. Rebetez, O. Dupont, M. Giroud, Theor and Appl. Climat. 95, 1-7 (2009)

22. D.K. Papanastasiou, D. Melas, H.D. Kambezidis, Glob. NEST J. 16, 5, 919-928 (2014)

23. A. Melkonyan, P. Wagner, Atmos. Environ. 67, 287-295 (2013)

24. G.A. Meehl, C. Tebaldi, Science 305, 5686, 994-997 (2004)

25. J. Kyselý, Int. J. Climatol. 30, 1, 89-109 (2010)

26. J. Strużewska, M. Jefimow, Acta Geoph. 64, 5, 1875-1902 (2016)

27. U. Kossowska-Cezak, Prace Geogr. 136, 9-30 (2014)

28. R. Twardosz, A. Batko, Int. J. Global Warming 4, 3-4, 261-272 (2012)

29. A. Krzyżewska, S. Wereski, Prz. Geofiz. 56, 1-2, 99-109 (2011)

30. G. Majewski, W. Rogula-Kozłowska, K. Rozbicka, P. Rogula-Kopiec, B. Mathews, A. Brandyk, Aerosol Air Qual. Res. 18, 636-654 (2018)

31. W. Rogula-Kozłowska, G. Majewski, K. Widziewicz, P. Rogula-Kopiec, M. Tytła, B. Mathews, M. Ciuka-Witrylak Atmospheric Pollution Research doi.org/10.1016/j.apr. 2018.08.004 (2018)

32. G. Majewski, K. Widziewicz, W. Rogula-Kozłowska, P. Rogula-Kopiec, K. Kociszewska, T. Rozbicki, M. Majder-Łopatka, M. Niemczyk Int. J. Environ. Res. Public Health 15, 2, 316 doi.org/10.3390/ijerph15020316 (2018)

33. A. Badyda, P. Dąbrowiecki, W. Lubiński, P.O. Czechowski, G. Majewski, Adv. Exp. Med. Biol., 755, 35 (2013)

34. K. Rozbicka, T. Rozbicki, Pol J Environ Stud 4, 25, 1675-1683 (2016)

35. L. Gawuć, M. Jefimow, J. Strużewska, in: I National Conference on „,Role of aerosols in the climate system”, 25-27 September 2013, Warsaw, Poland (2013)

36. D. Graczyk, Z.W. Kundzewicz, Acta Geophys. 62, 6, 1435-1449 (2014)

37. R. Twardosz, U. Kossowska-Cezak, Acta Geophys. 63, 1, 275-300 (2015) 